целей «на судах технического флота», называют главными. Двигатели СЭУ используют на речных судах, как правило, для производства электроэнергии - вспомогательные двигатели.

1. Тимофеев В.Н., Тузов Л.В., Безюков О.К., Жуков В.А., Тихонов Н.Ф., Тимофеев Д.В. Судовая энергосберегающая установка. Патент на полезную модель RU 166326 U1, 20.11.2016. Заявка № 2016119864/11 от 23.05.2016.

2. Тимофеев В.Н., Тихонов Н.Ф. Энергосберегающая установка речного судна. Сборник избранных статей по материалам научных конференций ГНИИ "Нацразвитие". Материалы конференций ГНИИ «НАЦРАЗВИТИЕ». Выпускающий редактор Ю.Ф. Эльзессер, Ответственный за выпуск С.В. Викторенкова. 2019. С. 277-281.

3. Тимофеев В.Н., Тихонов Н.Ф. Судовые термоэлектрические генераторы. Концепции устойчивого развития науки в современных условиях. сборник статей по итогам Международной научнопрактической конференции: в 6 частях. 2017. С. 169-178.

4. Вилисов Д.В. и др. Электрооборудование судов. СПб.: Элморфонд СЭТ, 2016г.— 412c.

5. Буров Н.И., Голубев В.К. и др. Справочник по информатике и эксплуатации судовой электроники. Одесса: Маяк, 2019,-179с.

6. Брыль А.И. Переменные режимы судовых турбин. Учебное пособие. - М, 2018.

7. Беляев И.Г. и др. Автоматизация процессов в судовой энергетике. Учебник для вузов, - М.: Транспорт, 2019.

8. Тимофеев В.Н., Тихонов Н.Ф. Повышение эффективности систем охлаждения судовых двигателей внутреннего сгорания с автоматическим регулированием теплового состояния. Сборник научных трудов профессорско-преподавательского состава Государственного университета морского и речного флота имени адмирала С.О. Макарова. Сборник научных статей. 2016. С. 339-347.

\title{
Васильева М.А. \\ Повышение надежности работы тепловых сетей при канальной прокладке
} ФГАОУ ВО «Московский Политехнический Университет» (Россия, Москва)

doi: 10.18411/lj-04-2021-286

\section{Аннотация}

Статья посвящена проблемам возникающим при транспортировке теплоносителя по тепловым сетям. Рассматривается вопрос, увеличения срока эксплуатации тепловых сетей, возможность избежать наружную коррозию труб возникающую со временем при эксплуатации сетей. Возможность применение таких теплоизоляционных материалов как: армопенобетон, пенополимерминерал и пенополиуретан.

Ключевые слова: эксплуатация, армопенобетон, пенополимерминерал пенополиуретан, теплоизоляция, коррозия, вентиляция, теплоснабжение

\section{Abstract}

The article is devoted to the problems that arise during the transport of heat carrier through heat networks. The issue of increasing the service life of heating networks, the possibility of avoiding external corrosion of pipes that occurs over time during the operation of networks is considered. The possibility of using such thermal insulation materials as: reinforced concrete, foam polymer mineral and polyurethane foam.

Keywords: operation, reinforced concrete, foam polymer mineral, polyurethane foam, thermal insulation, corrosion, ventilation, heat supply

Тепловые сети это довольно протяженные инженерные сооружения, по которым теплоноситель должен доставляться потребителю с наименьшими потерями тепла и расхода. Тепловые сети различают по различным признакам: 
— по способу прокладки: канальная, безканальная, надземная или подземная;

- по системам: радиальные (тупиковые) или кольцевые;

- трубопроводы бывают: магистральные, распределительные или ответвления и т.д.

На практике в основном применяют два типа прокладки сетей: канальную прокладку и надземную, причем около 85\% прокладки приходится на подземную канальную прокладку. Для этого есть объяснение. Основная часть тепловых сетей расположена в городах с высокой плотности застройки, с необходимым наличием разветвленной системой дорог о подъездных путей. Инженерные коммуникации, при этом, прокладываются под землей, чтобы не портить задуманный архитекторами ландшафт и уберечь людей от случайных чрезвычайных происшествий. Вся тепловая сеть прячется в специальные каналы (проходные или полупроходные) и дальше специалисты занимаются непосредственно обслуживанием данной сети.

Бесканальная прокладка используется в том случае, если при строительстве коммуникаций имеется доступное заводское производство изолированных труб, с подходящей хорошей изоляцией. Но, как правило, если трубопроводы тепловых сетей были заложены в каналах, то канальную прокладку стараются сохранить. Так же известно, что тепловые сети которые уложены в общих коллекторах дольше служат, т.к. их постоянно диагностируют, они имеют электрохимическую защиту и к ним есть доступ эксплуатирующего персонала. И ещё один немаловажный аспект: в стесненных городских условиях в каналах и тоннелях можно прокладывать различные коммуникации, что значительно сокращает площади для их прокладки.

Для увеличения срока службы тепловых сетей изучают различные причины, влияющие на их работу. Одной из основных причин повреждения тепловых сетей, а как следствие повреждения - сокращения срока эксплуатации, является наружная коррозия труб. Процесс наружной коррозии труб может быть вызван различными причинами:

— нарушение (или не качественная) изоляция трубопроводов;

- повышение влажности теплоизоляции трубопроводов;

— плохая гидравлическая защита сооружений при подземной (канальной) прокладки сетей теплоснабжения.

Для теплоизоляции тепловых сетей при надземной прокладке, традиционно использовали маты из минеральной ваты и стекловолокна. При канальной прокладки труб в качестве теплоизоляционных материалов применялись мягкие плиты и цилиндры из минеральной ваты и стекловолокна. При подземной без канальной прокладке, обычно применяют трубы с гидроизоляцией и теплоизоляцией, сделанной в заводских условиях.

Применяя теплоизоляцию труб из новых материалов, таких как армопенобетон, пенополимерминерал, пенополиуретан. Технические характеристики этих материалов различны, соответственно и технические решения по применению тепловой изоляции из этих веществ принимаются в каждом проектируемом случае в соответствии с рекомендациями строительных норм и в соответствии с расчетом.

Повышение влажности теплоизоляции приводит не только к коррозии тепловых сетей, но и к увеличению потерь тепла, транспортируемого потребителю. Наиболее простым и надёжным способом борьбы с увлажнением теплоизоляции, является проветривание каналов с тепловыми сетями атмосферным воздухом. При проветривании осушается воздух в каналах, снижается его влажность и предотвращается появление конденсата на поверхностях за счет повышения температуры точки росы.

Если канальная прокладка тепловых сетей сделана в не вентилируемом канале, это приведет к ускорению и усилению процессов коррозии, повышению влажности в 
канале. Вследствие этого сократиться срок службы сетей теплоснабжения, повысятся тепловые потери и возрастет количество ремонтов такой сети.

Вентиляция при канальной прокладке тепловой сети может быть естественной или принудительной. Применение или эффективность того или иного типа вентиляции обусловлено расчетом вентиляции подземного канала тепловой сети. Такой расчет выполняется в зависимости от различных параметров: площади канала; его расположения (вертикальное или горизонтальное); длины вентилируемого участка; высотного расположения вытяжных и приточных шахт; перепадов температур и других параметров.

Для более эффективной работы инженеров по проектированию сетей теплоснабжения существуют программы расчета вентиляции подземных каналов. Эти программы при расчете учитывают многие параметры работы тепловых сетей и помогают найти наиболее эффективное и рациональное решение вентилирования подземных каналов.

В системе теплоснабжения тепловые сети являются наиболее «слабым» звеном. Они очень протяженные, дорого стоят и на их строительство и ремонт необходимо много времени. При неправильной эксплуатации возникают частые аварии и сокращается срок службы тепловых сетей. При анализе факторов, влияющих на выбор применяемых технологий, зачастую оказывается, что отсутствие финансирования, производственных баз и опыта эксплуатации, приводит к применению «традиционных» методов ремонта и строительства тепловых сетей с использованием низко эффективных технологий и методов проведения работ. Следовательно для повышения эффективности работы всей системы теплоснабжения, нужно более внимательно изучать и решать вопросы улучшения работы «слабых» звеньев, применяя инновационные технологии и передовые инженерные разработки.

Перед человеком всегда стояла проблема сбережения энергоресурсов, рационального их расходования и использование вторичных энергетических ресурсов (ВЭР). Этот аспект развития энергоёмких отраслей был и всегда будет в поле зрения экономистов, хозяйствующих субъектов, природоохранных организаций. Успешное развитие экономики любого государства будет зависеть от эффективности энергосбережения, и как следствие ресурсосбережения на всех участках любого производства, его сетей, оборудования и грамотного управления всем этим.

\section{$* * *$}

1. Яковлев Б. В. Предотвращение коррозионной повреждаемости тепловых сетей // Энергоэффективность. -2002. - №4. - С. 9-10.

2. Воронин С.М. К вопросу о вентиляции камер и каналов тепловых сетей // Новости теплоснабжения. - 2001. - № 8. - С. 19-22.

Синюков В.В., Щукин А.В.

Эффективность системы энергообеспечения средств наземного обслуживания воздушного судна на основе совершенствования подготовки персонала

Военный учебно-научный центр военно-воздушных сил «Военно-воздушная академия имени профессора Н.Е. Жуковского и Ю.А. Гагарина»

(Россия, Воронеж)

doi: 10.18411/lj-04-2021-287

\section{Аннотация}

Рассмотрена система энергообеспечения аэродрома государственной авиации и её составляющие. Получено выражение, позволяющее оценить эффективность системы энергообеспечения средств наземного обслуживания воздушного судна. Определено влияние качества подготовки и профессиональной квалификации персонала системы 